\title{
The adenovirus E1A-associated 130-kD protein is encoded by a member of the retinoblastoma gene family and physically interacts with cyclins $A$ and $E$
}

\author{
Yun Li, ${ }^{1}$ Christina Graham, ${ }^{1}$ Susan Lacy, ${ }^{1}$ Alessandra M.V. Duncan ${ }^{2}$ and Peter Whyte ${ }^{1,3}$ \\ ${ }^{1}$ Institute for Molecular Biology and Biotechnology, McMaster University, Hamilton, Ontario, Canada L8S 4K1; \\ ${ }^{2}$ Department of Pathology, Queen's University and Kingston General Hospital, Kingston, Ontario, Canada K $712 \mathrm{~V} 7{ }^{1}$
}

The adenovirus E1A proteins form complexes with a group of cellular proteins, including a protein of $130 \mathrm{kD}$. E1A-associated p130 was purified through coimmunoprecipitation with E1A, and sequence data from four tryptic peptides was obtained. Oligonucleotides derived from the peptide sequences were used to clone a 4.85-kb cDNA. The cDNA contained an 1139-amino-acid open reading frame with homology to the retinoblastoma protein and E1A-associated p107 but was more closely related to p107. In vitro-translated p130 bound to E1A, and anti-p130 antibodies detected p130 in immunoblots of E1A immunoprecipitates. p130 was also detected in immunoprecipitates of cyclins $A$ and $E$ and was an efficient substrate in vitro for kinase activities associated with these cyclins. The p130 gene mapped to chromosome 16q12.2-13, a region that undergoes allelic loss in several types of tumors, including hepatocellular, prostate, and breast carcinomas.

[Key Words: p130; p107; pRb; ElA; cyclins]

Received August 13, 1993; revised version accepted October 14, 1993.

The adenovirus E1A proteins play an important role in the early stages of adenovirus infection by stimulating host cells into a cycling state and activating transcription from the other early regions of the viral genome. Several lines of evidence suggest that E1A is capable of overcoming host cell mechanisms that restrict progression through the cell cycle. Induction of cellular DNA synthesis upon adenovirus infection of quiescent cells is dependent on E1A (Bellet et al. 1985; Stabel et al. 1985; Kaczmarek et al. 1986). Expression of E1A is sufficient to immortalize primary rodent cells (Houwelling et al. 1980; Ruley 1983). E1A is also able to complement certain other oncogenes to transform primary cells (Ruley 1983|. Finally, expression of E1A can block terminal differentiation of certain established cell lines (Maruyama et al. 1987; Webster et al. 1988).

Insight into the mechanism of the functions of ElA has come from studies of the interactions between E1A and a group of cellular proteins (Yee and Branton 1985; Harlow et al. 1986). Regions of the ElA protein required for transformation correlate with regions required for interactions with particular cellular proteins, suggesting that these interactions facilitate the transforming func-

${ }^{3}$ Corresponding author. tions of E1A (Egan et al. 1988; Whyte et al. 1989; Giordano et al. 1991; Howe and Bayley 1992).

Several of the E1A-associated cellular proteins have been identified; these include $\mathrm{pRb}$ (the product of the retinoblastoma tumor suppressor gene), cyclins $\mathrm{A}$ and $\mathrm{E}$, and the cdk2 kinase (Whyte et al. 1988; Giordano et al. 1989; Pines and Hunter 1990; Tsai et al. 1991; Faha et al. 1993). A cDNA encoding the E1A-associated p107 protein has been isolated and found to encode a protein related to $\mathrm{pRb}$ (Ewen et al. 1991). Interactions between ElA and pRb, p107, and cyclin A are dependent on conserved regions 1 and 2 of E1A /CR1 and CR2, respectively) (Egan et al. 1988; Whyte et al. 1989; Giordano et al. 1991; Howe and Bayley 1992|. These regions are not only conserved among the various serotypes of adenovirus but also in the large $T$ antigens of the polyoma family of viruses and the E7 proteins from the human papillomaviruses (Kimelman et al. 1985; Stabel et al. 1985; Phelps et al. 1988; Dyson et al. 1989b). The T antigens and E7 viral proteins are capable of interacting with many of the same cellular proteins as E1A (DeCaprio et al. 1988; Dyson et al. 1989a,b, 1990; Ewen et al. 1989).

Further understanding of the function of certain E1Aassociated proteins has come from studies of the E2F transcription factors. E2F sites were first identified as transcription factor binding sites located within the ad- 
enovirus E2 promoter (for review, see Nevins 1992). E1A induces transcription through these sites. E2F transcription factors exist in either a free uncomplexed form or in a complex with other cellular proteins. In the uncomplexed form, E2F appears to activate transcription. In contrast, transcriptional activation is suppressed when E2F is sequestered into complexes by binding to other cellular proteins (Bagchi et al. 1990; Hamel et al. 1992; Heibert et al. 1992; Weintraub et al. 1992; Zamanian and La Thangue 1992, 1993; Schwarz et al. 1993). Analyses of the E2F complexes have revealed that several different complexes exist, including E2F complexed to $\mathrm{pRb}$ and E2F complexed to p107 (Bagchi et al. 1991; Bandara and La Thangue 1991; Chellappan et al. 1991; Chittenden et al. 1991; Mudryj et al. 1991; Cao et al. 1992; Devoto et al. 1992; Lees et la. 1992; Pagano et al. 1992; Shirodkar et al. 1992). The E2F complexes containing p107 can also include cyclin A and cdk2 or cyclin E and cdk2. These data indicate that regulation of transcription through E2F sites involves many components and is strictly regulated. Interaction of viral transforming proteins, such as E1A, SV40 T antigen, or HPV E7, with pRb or p107 disrupts their interaction with E2F complexes. Only the uncomplexed forms of E2F are observed in extracts from cells expressing these viral oncoproteins (Bagchi et al. 1990; Cao et al. 1992; Chellappan et al. 1991).

Phosphorylation of $\mathrm{pRb}$ occurs in a cell cycle-dependent manner and is thought to be a key regulatory mechanism for pRb activity (Buchkovich et al. 1989; Chen et al. 1989; DeCaprio et al. 1989, Mihara et al. 1989|. During the $G_{1} / G_{0}$ stages of the cell cycle $p R b$ is in the hypophosphorylated form which is thought to be the functionally active form (Ludlow et al. 1989). Only the hypophosphorylated form of $\mathrm{pRb}$ is capable of participating in E2F complexes (Chellappan et al. 1991; Helin et al. 1992; Kaelin et al. 1992). Mapping of phosphorylation sites suggests that cdc2 or a related kinase is responsible for phosphorylation of $\mathrm{pRb}$ (Lees et al. 1991; Lin et al. 1991). Although regulation of p107 by phosphorylation has not yet been established, p107 is found in complexes with cyclins A and E and cdk2 (Faha et al. 1992, 1993). In vitro kinase reactions suggest that p107 is a major target for the cyclin-associated kinases (Faha et al. 1992; Peeper et al. 1993).

Another protein, $\mathrm{p} 130$, has been found to associate with E1A (Harlow et al. 1986). Like pRb and p107, p130 interacts with conserved regions 1 and 2 of E1A and can interact, at least in vitro, with synthetic peptides derived from the HPV E7 protein (Giordano et al. 1991; Dyson et al. 1992). In this study we describe the isolation of a cDNA for p130 and demonstrate its ability to bind to E1A and to cyclins $\mathrm{A}$ and $\mathrm{E}$.

\section{Results}

Isolation of a cDNA encoding the E1A-associated $p 130$

As a first step toward isolating a cDNA for p130, the pl30 protein was gel purified from immunoaffinity-purified E1A complex to obtain protein sequence data (for details, see Materials and methods). Amino-terminal sequence data were obtained from four tryptic peptides using automated Edman degradation. Somewhat surprisingly, all four peptides had recognizable similarity to regions of the p107 protein. On the basis of peptide sequences and knowledge of the p107 sequence, oligonucleotide primers were constructed and used to generate a partial cDNA using PCR. Oligonucleotide primers derived from peptides 1 and 3 generated a PCR product containing an open reading frame that included the sequence of peptide 2 and had homology to p107 (Fig. 1). Using this PCR product as an initial probe, three overlapping cDNAs were obtained (see Materials and methods for details). The resulting composite cDNA was 4.85 $\mathrm{kb}$ and encoded an open reading frame of 1139 amino acids beginning with an AUG. The start codon was preceded by 69 nucleotides of untranslated 5'-flanking sequences, which included two in-frame stop codons (Fig. 1). The cDNA also included 1364 nucleotides of $3^{\prime}$-untranslated sequences. All four peptides that were sequenced from the purified pl30 protein were encoded within the open reading frame.

Northern analysis of poly(A)-selected mRNA from several cell lines identified a doublet of mRNA species of approximately $4.8-5.0 \mathrm{~kb}$, the same size as the p130 cDNA (Fig. 2). This indicated that our cDNA represents most or all of the p130 mRNA. The source of heterogeneity giving rise to the two mRNA species, which was reproducibly present in all cell lines examined, is unknown.

\section{p130 forms a complex with E1A}

Although the p130 cDNA encoded all four tryptic peptides that had been sequenced, we sought additional evidence to support the authenticity of the p130 cDNA. Monoclonal antibodies raised against a glutathione $S$ transferase (GST)-p130 fusion protein were used in immunoblots to detect p130 in E1A immunoprecipitates from 293 cells (Fig. 3A). Immunoblots of E1A immunoprecipitates were probed with three different monoclonal antibodies to p130 and an anti-peptide antiserum to p107 as a control. Each of the monoclonal antibodies recognized p130 present in the E1A immunoprecipitate. The monoclonal antibodies also reacted against other proteins present in the E1A/cellular protein complex, including p107 and proteins migrating at the same positions as the E1A-associated $90-$ and $80-\mathrm{kD}$ proteins. In addition, the $\mathrm{Z} 38$ antibody reacted against a protein that migrated slightly faster than p107 and was present in both the E1A and control immunoprecipitate lanes indicating that it is not an E1A-associated protein. Detection of pl30 coimmunoprecipitating with E1A using antibodies raised to a GST-p130 fusion protein supported the conclusion that the cDNA that we had isolated encodes p130. The cross-reactivity of our monoclonal antibodies with several other cellular proteins present in the E1A complex suggested that these proteins are related to $\mathrm{p} 130$.

To confirm that the protein encoded by our p130 cDNA was capable of binding to E1A, in vitro-synthe- 


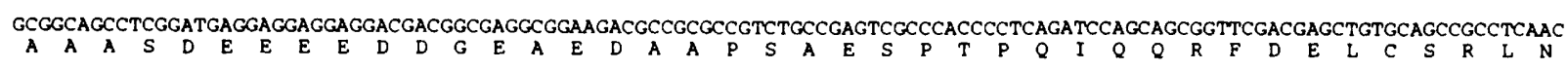

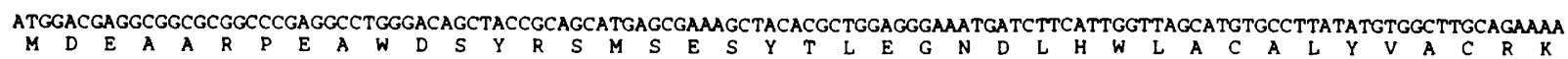

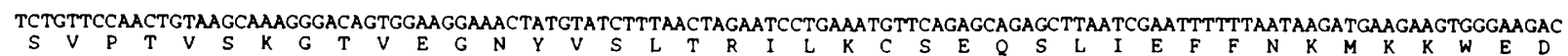

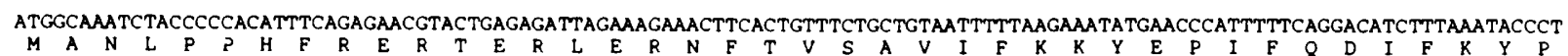

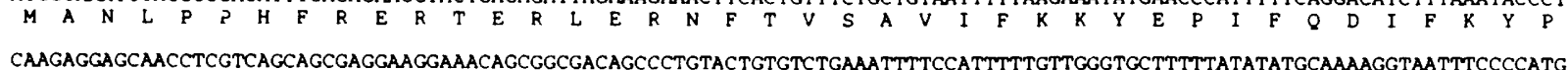

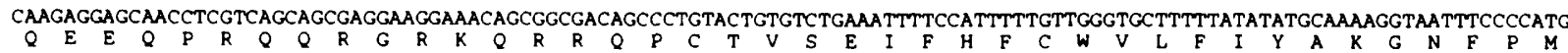

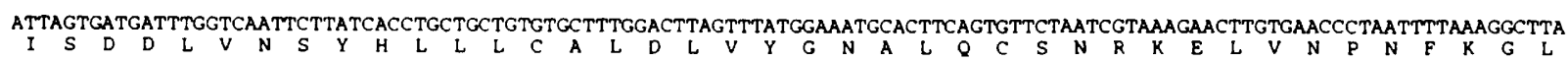

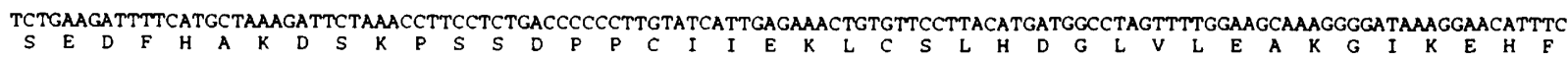
TGGAAACCCTATATTAGGAAACTTTATGAAAAAAACCTCCTTAAGGGAAAAGAAGAAAATCTCACTGGGTTTCTAGAACCTGGGAACTTTGGAGAGAGTTTTAAAGCCATCAATAAGGCC TATGAGGAGTATGTTTTATCTGTTGGGAATTTAGATGAGCGGATATTTCTTGGAGAGGATGCTGAGGAGGAAATTGGGACTCTCTCAAGGTGTCTGAACGCTGGTTCAGGAACAGAGACT

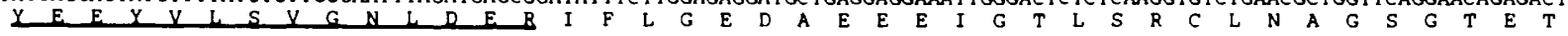
GCTGAAAGGGTGCAGATGAAAAACATCTTACAGCAGCATTTTGACAAGTCCAAAGCACTTAGAATCTCCACACCACTAACTGGTGTTAGGTACATTAAGGAGAATAGCCCTTGTGTGACT

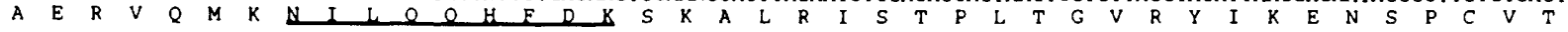
CCAGTTTCTACAGCTACGCATAGCTTGAGTCGTCTTCACACCATGCTGACAGGCCTCAGGAATGCACCAAGTGAGAAACTGGAACAGATTCTCAGGACATGTTCCAGAGATCCAACCCAG GCTATTGCTAACAGACTGAAAGAAATGTTTGAAATATATTCTCAGCATTTCCAGCCAGACGAGGATTTCAGTAATTGTGCTAAAGAAATTGCCAGCAAACATTTTCGTTTTGCGGAGATG

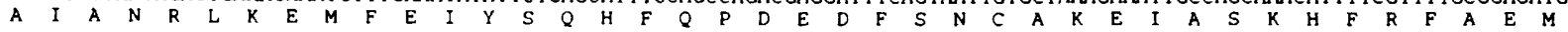
CTTTACTATAAAGTATTAGAATCTGTTATTGAGCAGGAACAAAAAAGACTAGGAGACATGGATTTATCTGGTATTCTGGAACAAGATGCATTCCACAGATCTCTCTTGGCCTGCTGCCTT

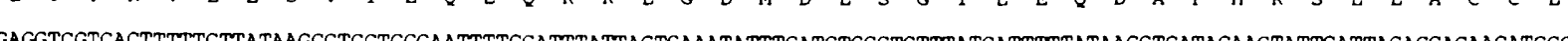

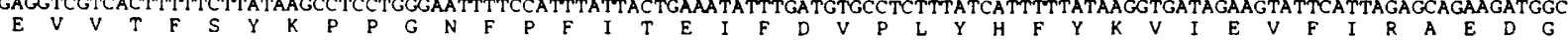
CTTTGTAGAGAGGTGGTAAAACACCTTAATCAGATTGAAGAACAGATCTTAGATCATTTGGCATGGAAACCAGAGTCTCCACTCTGGGAAAAAATTAGAGACAATGAAAACAGAGTTCCT ACATGTGAAGAGGTCATGCCACCTCAGAACCTGGAAAGGGCAGATGAAATTTGCATTGCTGGCTCCCCTTTGACTCCCAGAAGGGTGACTGAAGTTCGTGCTGATACTGGAGGACTTGGA

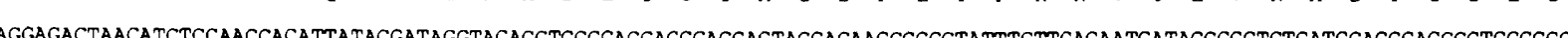

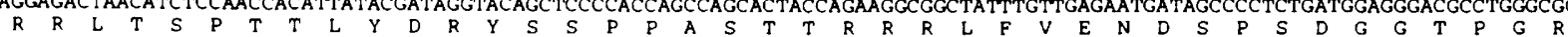
ATGCCCCCACAGCCCCTAGTCAATGCTGTCCCTGTGCAGAATGTATCTGGGGAGACTGTTTCTGTCACACCAGTTCCTGGACAGACTTTGGTCACCATGGCAACCGCCACTGTCACAGCC AACAATGGGCAAACGGTAACCATTCCTGTGCAAGGTATTGCCAATGAAAATGGAGGGATAACATTCTTCCCTGTCCAAGTCAATGTTGGGGGGCAGGCACAAGCTGTGACAGGCTCCATC

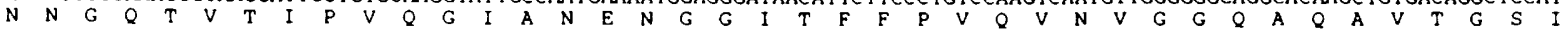
CAGCCCCTCAGTGCTCAGGCCCTGGCTGGAAGTCTGAGCTCTCAACAGGTGACAGGAACAACTTTGCAAGTCCCTGGTCAAGTGGCCATTCAACAGATTTCCCCAGGTGGCCAACAGCAG

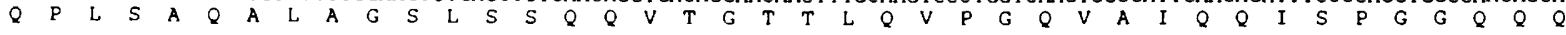
AAGCAAGGCCAGTCTGTAACCAGCAGTAGTAATAGACCCAGGAAGACCAGCTCTTTATCGCTTTTCTTTAGAAAGGTATACCATTTAGCAGCTGTCCGCCTTCGGGATCTCTGTGCCAAA CTAGATATTTCAGATGAATTGAGGAAAAMATTCTGGACCTGCTTTGAATTCTCCATAATTCAGTGTCCTGABCTMATGATG

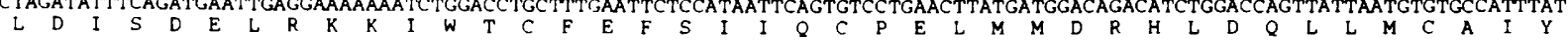
GTGATGGCAAAGGTCACAAAAGAAGATAAGTCCTTCCAGAACATTATGCGTTGTTATAGGACTCAGCCGCAGGCCCGGAGCCAGGTGTATAGAAGTGTTTTGATAAAAGGGAAAAGAAAA

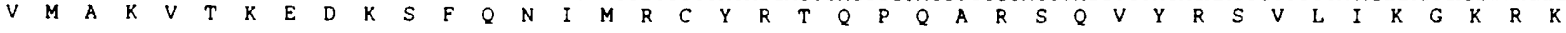
AGAAGAAATTCTGGCAGCAGTGATAGCAGAAGCCATCAGAATTCTCCAACAGAACTAAACAAAGATAGAACCAGTAGAGACTCCAGTCCAGTTATGAGGTCAAGCAGCACCTTGCCAGTT

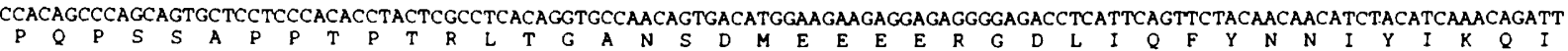

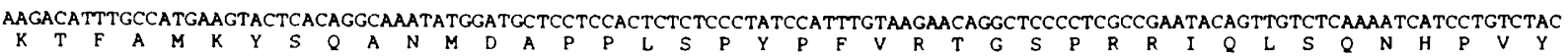

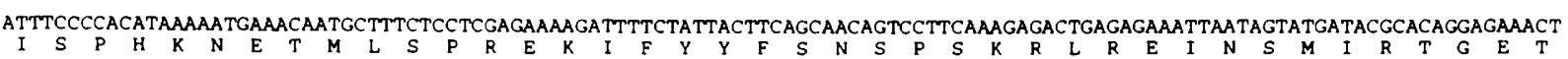
CCTACTAAAAAGAGAGGAATTCTTTTGGAAGATGGAAGTGAATCACCTGCAAAAAGAATTTGCCCAGAAAATCATTCTGCCTTATTACGCCGTCTCCAAGATGTAGCTAATGACCGTGGT

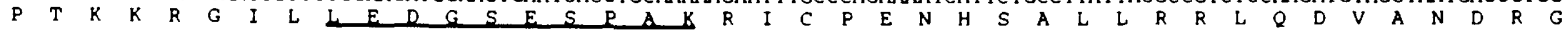
TCCCACTGAGGTTAGTCTCTTGTATTAAACTCTTCACAAAATCTGTTTAGCAGCAGCCTTTAATGCATCTAGATTATGGAGCTTTTTTCCTTAATCCAGCTGATGAGTTACAGCCTGTTA $S \mathrm{H}$ *

GTAACATGAGGGGACATTTTGGTGAGAAATGGGACTTAACTCCTTCCAGTGTCCTTAGAACATTTTAATTCATCCCAACTGTCTTTTTTTCCCTACCACTCAGTGATTACTGTCAAGGCT GCTTACAATCCAAACTTGGGTTTTTGGCTCTGGCAAAGCTTTTAGAAATACTGCAAGAAATGATGTGTACCCAACGTGAGCATAGGAGGCTTCTGTTGACGTCTCCAACAGAAGAACTGT GTTTCAAGTTCAATCCTACCTGTTTTGTGGTCAGCTGTAGTCCTCATAAAAAGCAAAACAAAAATTAGGTATTTTGTCCTAAAACACCTGGTAGGAGTGTGTGATTTTTTGCATTCCTGA CAAAGGAGAGCACACCCAGGTTTGGAGGTCCTAGGTCATTAGCCCTCGTCTCCCGTTCCCTTTTGTGCACATCTTCCCTCTCCCCATTCGGTGTGGTGCAGTGTGAAAAGTCCTTGATTGT TCGGGTGTGCAATGTCTGAGTGAACCTGTATAAGTGGAGGCACTTTAGGGCTGTAAAATGCATGATTTTGTAACCCAGATTTTGCTGTATATTTGTGATAGCACTTTCTACAATGTGAAC TTTATTAAATACAAAACTTCCAGGCTAAACATCCAATATTTTCTTTAATGCTTTTATATTTTTTTTAAAATGTTAAAACCCCTATAGCCACCTTTTGGGAATGTTTTAAAATTCTCCAGTTT TTTGTTATA TAGGGATCAACCAGCTAAGAAAAGATTTTAAGTCAAGTTGATTGAGGGGATTAATATGAAAACTTATGACCTCTCCTTTAGGAGGGAGTTATCTAAAAGAAATGTCTAT TAAGGTGATATATTTAAAAATATTTTTGGGTGTTCCTGGCAGTTTAAAAAAATTGGTTGGAGAATTTAGGTTTTTATTAGTACCATAGTACCATTTATACAAATTAGAAAATGTTATTTA ACAGCTGAATTATCTATACATATCTTTATTAATCACTATTGTTCCAGCAGTTTTCAAGTCAAATTAATAATCTTATTAGGGAGAAAATTCAATTGTAAATTGAATCAGTATAAACAAAGT GATAAGTGTATTTTTCAATAAAGCATTTATAAATTAAAAAAAAAAAAAAAAAA

Figure 1. (See facing page for legend.) 


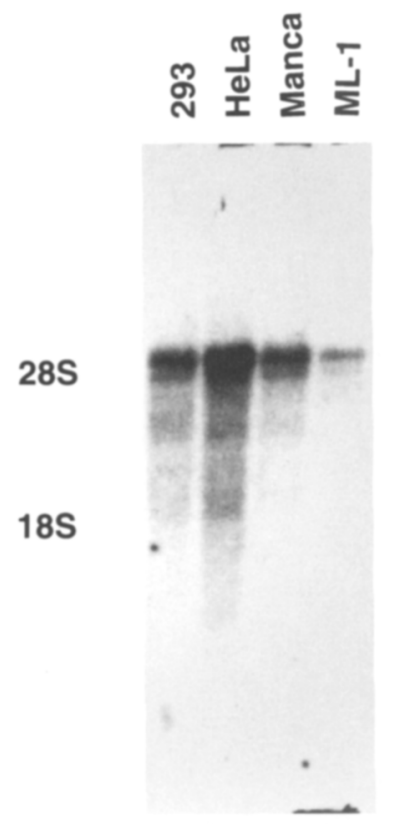

Figure 2. Northern analysis of P130 mRNA. Twenty micrograms of poly(A)-selected RNA from several cell lines was run on a $1 \%$ formaldehyde-agarose gel, blotted to Hybond-N (Amersham), and probed with ${ }^{32} \mathrm{P}$-labeled p130 cDNA.

sized p130 was tested for its ability to bind to E1A. For these experiments a shorter cDNA that does not encode the amino-terminal portion of the p130 protein was used. When a full-length cDNA was used, in vitro transcription took place efficiently but no translation product was observed following in vitro translation reactions. This may have been the result of secondary structures formed by the G/C-rich region surrounding the first methionine codon. The shorter cDNA used in these experiments began at nucleotide 262 and probably initiated translation at methionine 73 . A translation product migrating at $\sim 110 \mathrm{kD}$ and a second translation product of $\sim 68 \mathrm{kD}$ were produced (Fig. $3 \mathrm{~B}$ ). The smaller protein probably represents a polypeptide initiated from an internal methionine. Both products could be immunoprecipitated with an anti-peptide serum raised against an epitope located near the carboxyl terminus of $\mathrm{pl} 30$ (data not shown).

Radioactively labeled in vitro-translated p130 was mixed with lysates from 293 cells to allow the in vitrotranslated p130 to bind to E1A. E1A was then immunoprecipitated from the extract. The in vitro-translated p130 proteins coimmunoprecipitated with E1A but were not present in the immunoprecipitates when a negative control antibody was used (Fig. 3B). Both the 110- and $68-\mathrm{kD}$ forms of the translation product were capable of complexing with E1A indicating that a considerable amount of amino-terminal sequences are dispensable for the interaction with ElA.

In a second experiment to demonstrate the ability of p130 to interact with E1A, in vitro-translated p130 was incubated with a GST-E1A fusion protein containing amino acids $86-150$ of E1A. This portion of E1A includes the CR2 region of E1A, which has been shown to be sufficient for interaction with p130 in vitro (Dyson et al. 1992). In vitro-translated p130 was capable of binding to the GST-E1A fusion protein but not to GST alone (Fig. $3 \mathrm{C})$. Addition of an E1A CR2 peptide as a competitor abolished detectable interaction between the in vitrotranslated p130 and the GST-E1A fusion protein confirming that the interaction was dependent on the CR2 region of the GST-E1A protein.

Finally, proteolytic peptide profiles of in vitro-translated p130 were compared with those of $\mathrm{p} 130$ isolated through coimmunoprecipitation with ElA from 293 cells. Gel-purified p130 was subjected to proteolytic digestion by varying amounts of V8 protease, and the peptides were separated by gel electrophoresis (Fig. 3D). Identical peptide profiles were observed for the two p130 samples confirming that our cDNA did encode the E1Aassociated $\mathrm{p} 130$.

\section{$p 130$ is structurally related to $p R b$ and $p 107$}

Comparison of the p130 sequence to the sequences of $\mathrm{pRb}$ and $\mathrm{p} 107$ revealed that these proteins are related (Fig. 4A). Extensive sequence similarity exists between p130 and p107 throughout most of the reading frame of the two proteins. Overall, these two proteins are identical at slightly greater than $50 \%$ of the residues. p130 and $\mathrm{pRb}$ are identical at $22 \%$ of residues. Among the three members of the family, p130 is slightly more distant than p107 from pRb. Conservation of residues was clustered within particular regions of the three proteins (schematically represented in Fig. 4A). Regions 1-6 are highly conserved in each of the three proteins, except region 3 , which is poorly conserved between p130 and $\mathrm{pRb}$. For regions 1 and 6 , the sequence similarity between p130 and p107 extends over a greater portion of the protein than the sequence similarity between p130 and $\mathrm{pRb}$. The regions most strongly conserved among the three proteins are located within the E1A/T antigenbinding region or "pocket" region defined by mutational studies on pRb (Hu et al. 1990; Huang et al. 1990; Kaelin et al. 1990). p130 and $\mathrm{pRb}$ also share a related region located near the amino terminus of each protein. This region (P/A box, Fig. 4A) is rich in proline and alanine residues.

The spacer region is the part of $\mathrm{pRb}$ and $\mathrm{p} 107$ that

Figure 1. Nucleotide sequence of p130 cDNA and encoded protein sequence. The coding strand of the p130 cDNA is shown. Amino acid sequence of the open reading frame is shown below beginning at the first methionine and continuing until the first termination codon $\left({ }^{*}\right)$ located at nucleotide 3487 . The four underlined stretches of amino acids correspond to the tryptic peptides that were sequenced (peptides $1-4$, numbered by position in the open reading frame). 
Li et al.

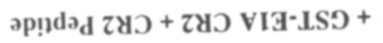

z\&ว ViG-ISS +

LSD +

0E Id paje|sued $\mathbf{L}$

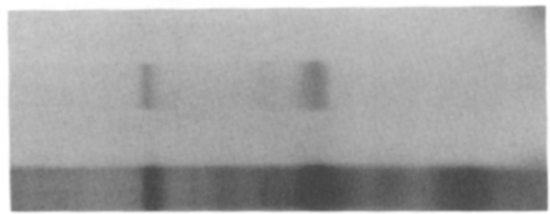

$\frac{\mathrm{m}}{1}$

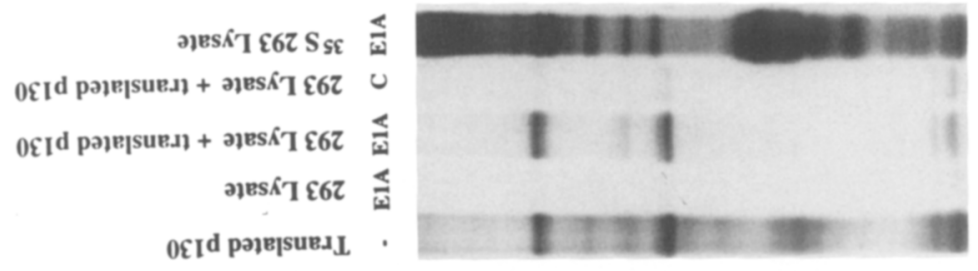

商

1111
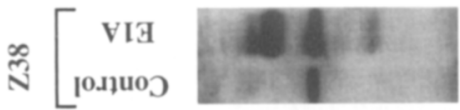

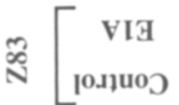

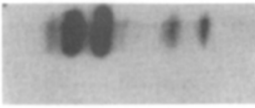

$\overline{\bar{N}}\left[\begin{array}{c}\text { VIA } \\ \text { ןonuos }\end{array}\right.$

11

产 $\left[\begin{array}{c}\text { VIG } \\ \text { [o.juos }\end{array}\right.$

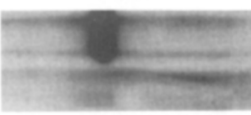

$\stackrel{\frac{0}{2}}{人} \cong$

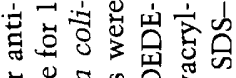

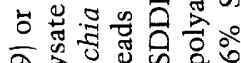

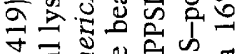
券志至会

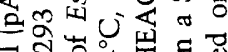

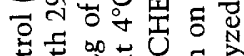

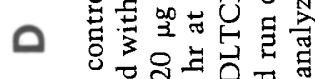

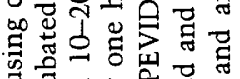

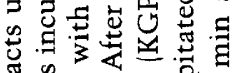

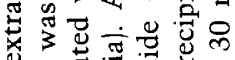

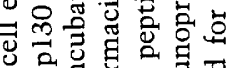
๓

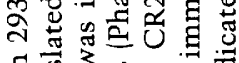

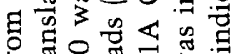
넌욜 四

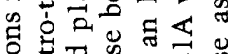
声它 $\Xi \frac{\pi}{0} \frac{\pi}{3} \overline{0}$

$\mathcal{U}$

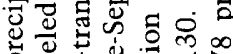

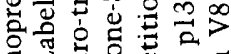

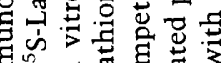

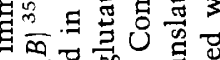

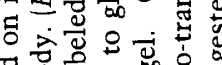

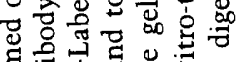

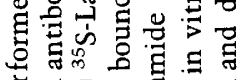

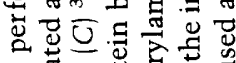

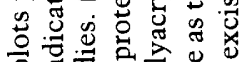

$m$

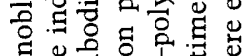

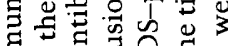

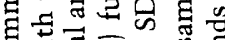

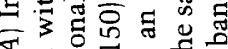

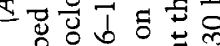

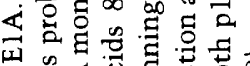

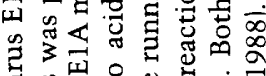

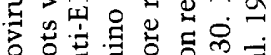

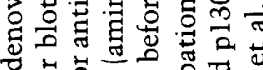

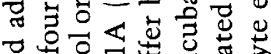

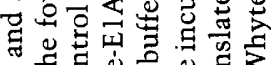

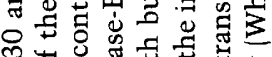

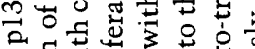

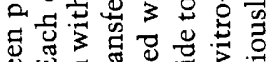

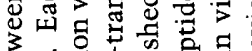

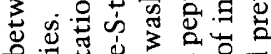

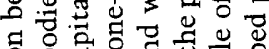

$<$

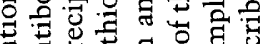

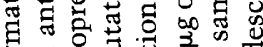
굴

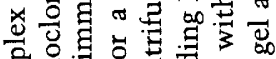

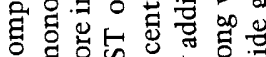

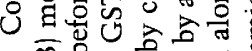

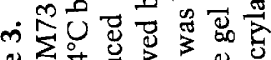

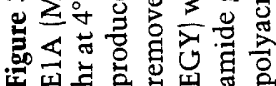


A p107

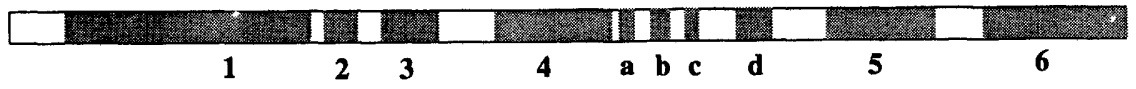

p130

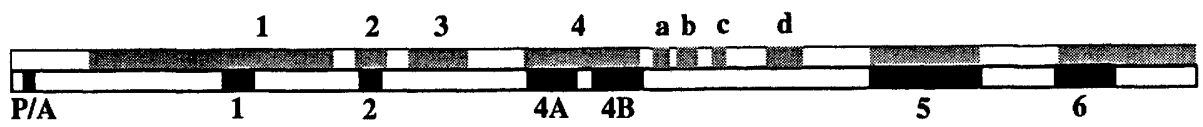

RB

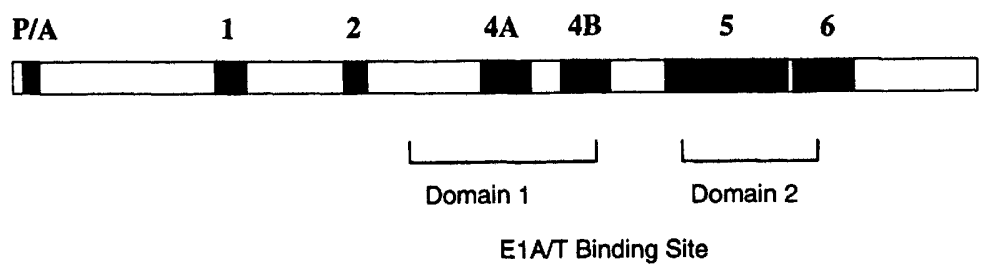

B

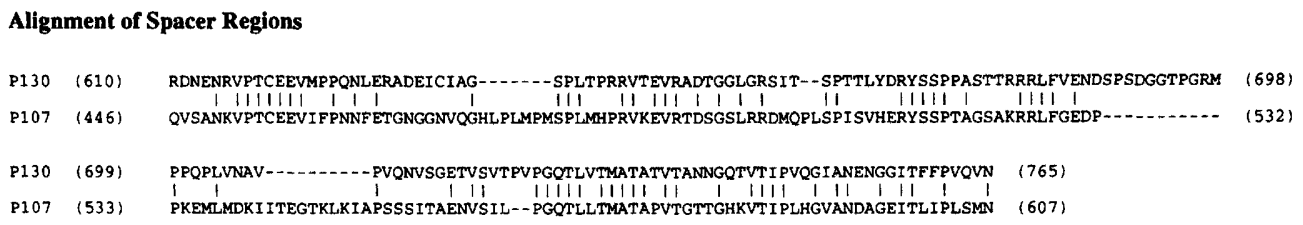

Figure 4. Homology between p130 and p107 or pRb. $(A)$ The p130 sequence was compared with that of pRb and p107 (Friend et al. 1987; Ewen et al. 1991; Zhu et al. 1993). Strongly conserved regions shared between pl30 and pl07 are illustrated by the shaded regions. Strongly conserved regions shared between $\mathrm{p} 130$ and $\mathrm{pRb}$ are shown in black. P/A is a proline/alanine-rich region. $(B)$ Sequence alignment of the similar portions of the p130 and p107 spacer regions.

intervenes the two regions comprising the E1A/T-binding pocket. 130 contains a spacer region that is similar to that of p107 but not to the pRb spacer. Similarity between the 130 and p107 spacers occurs in four clusters distributed throughout most of the spacer region (Fig. 4A,B). Toward the carboxyl end of the spacers the sequences diverge and show no similarity. Thus, the spacer regions of p130 and p107 may be functionally similar to each other but different from the spacer of $\mathrm{pRb}$.

\section{p130 forms a complex with members of the cyclin family}

Cyclins $A$ and $E$ are each capable of interacting with the p107 protein (Faha et al. 1992, 1993). In addition, in vitro kinase reactions of immunoprecipitated cyclin $\mathrm{A}$ or cyclin E result in the phosphorylation of p107 and several other proteins, including one migrating at the same position as p130. The interaction between cyclin A and p107 requires the p107 spacer region (Ewen et al. 1992), which is similar in sequence to the spacer of $\mathrm{pl} 30$. Consequently, we examined the possibility that cyclin A and perhaps other cyclins interact with p130. Several human cyclins were immunoprecipitated, and immunoblots were probed for p107 and p130 using the $\mathrm{Z} 11$ monoclonal antibody. Both p130 and p107 were found to coimmunoprecipitate with cyclins A and E (Fig. 5A).

An anti-peptide antiserum, raised against a carboxyterminal epitope from cyclin D1, immunoprecipitated a complex that included p107 but not p130 (Fig. 5A). However, it is likely that the anti-cyclin D1 peptide serum recognizes other members of the cyclin $\mathrm{D}$ family given the conservation of carboxy-terminal sequences (Xiong et al. 1992). Furthermore, p107 was present in cyclin D immunoprecipitates from 293 cells that have very low levels of cyclin D1 (Xiong et al. 1991). It is possible that the anti-cyclin Dl antibody is recognizing another D cyclin that interacts with p107 but not p130. Further work will be necessary to determine which member of the cyclin D family is coprecipitating with p107 in this assay. Nonetheless, it is intriguing that a cyclin immunoprecipitated by this antibody discriminates between p107 and p130.

The presence of p107 and p130 in complexes with cyclins raises the possibility that p107 and p130 are being targeted by the cyclins for phosphorylation by cyclin/ cdk complexes. In vitro kinase reactions following immunoprecipitations using the anti-cyclin antibodies resulted in phosphorylation of p107 and p130 in the cyclin 
Li et al.
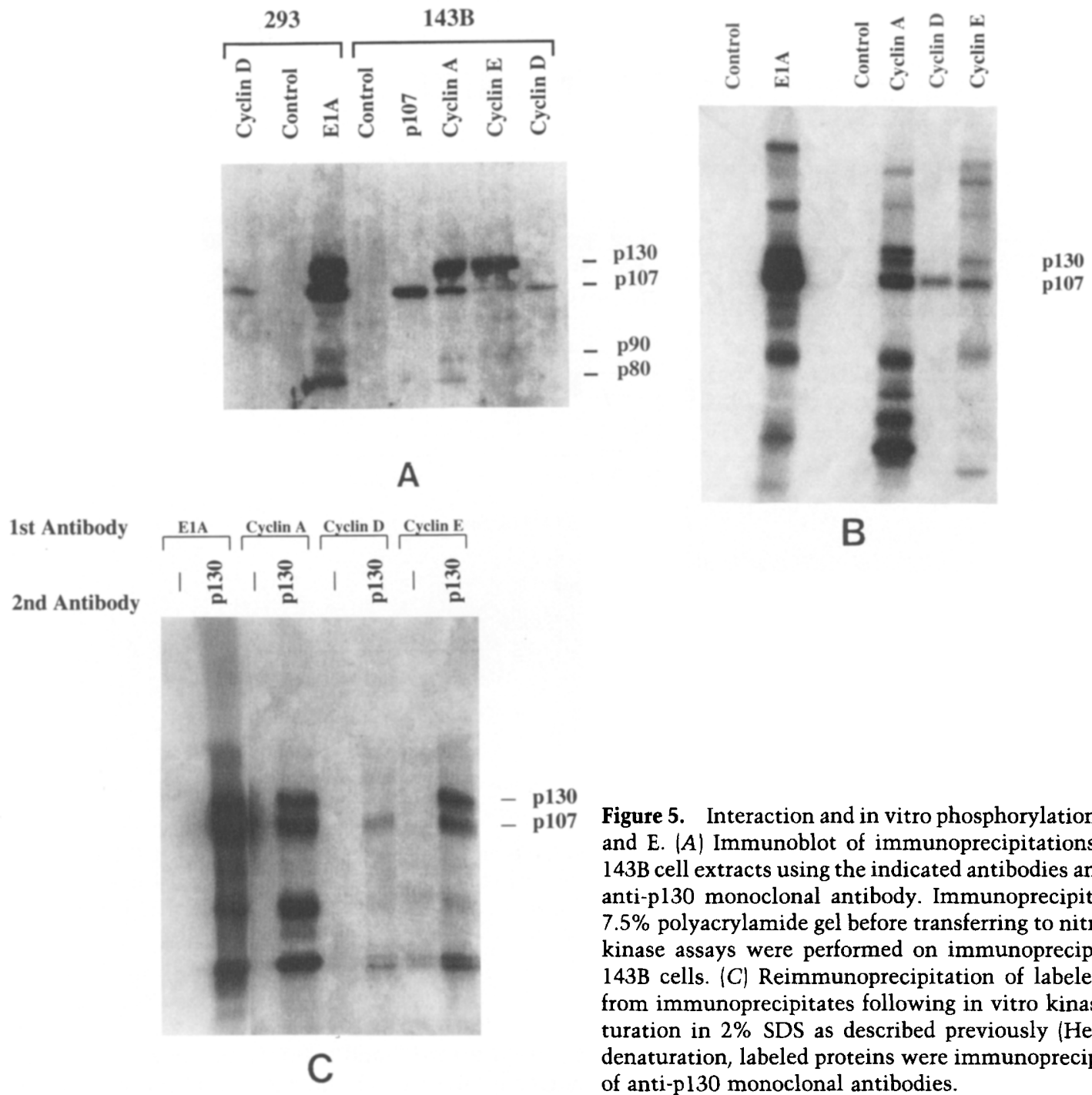

Figure 5. Interaction and in vitro phosphorylation of p130 with cyclin A and E. (A) Immunoblot of immunoprecipitations from either 293 and $143 \mathrm{~B}$ cell extracts using the indicated antibodies and probed with the Z11 anti-p130 monoclonal antibody. Immunoprecipitations were run on a $7.5 \%$ polyacrylamide gel before transferring to nitrocellulose. $(B)$ In vitro kinase assays were performed on immunoprecipitates from unlabeled 143B cells. $(C)$ Reimmunoprecipitation of labeled p130 and p107 was from immunoprecipitates following in vitro kinase reactions and denaturation in $2 \%$ SDS as described previously (Helin et al. 1992). After denaturation, labeled proteins were immunoprecipitated with a cocktail of anti-pl30 monoclonal antibodies.

A and cyclin E complexes and phosphorylation of p107, but not p130, in the cyclin D complex (Fig. 5B). The identity of these proteins in the ElA and cyclin immunoprecipitates was confirmed by denaturing the complex after the kinase reaction and reimmunoprecipitating the ${ }^{32} \mathrm{P}$-labeled $\mathrm{p} 107$ and $\mathrm{p} 130$ proteins directly using a cocktail of the anti-p130 monoclonal antibodies (Fig. 5C).

\section{Chromosomal localization of the p130 gene}

p130 is structurally related to $\mathrm{pRb}$, a known tumor suppressor protein. One possibility is that pl 30 also functions as a tumor suppressor gene. Allelic losses at specific chromosomal regions have been associated with various types of cancer and are postulated to be the sites of tumor suppressor genes. To determine the chromosomal localization of the $\mathrm{p} 130$ gene, ${ }^{3} \mathrm{H}$-labeled $\mathrm{p} 130$ cDNA was used to probe metaphase chromosomes from human peripheral blood lymphocytes. Analysis of the distribution of 200 silver grains (Fig. 6, bottom) following in situ hybridization revealed a significant clustering of grains (51 of 200) in the q11.2-q21 region of chromosome $16(\mathrm{P}<0.0001)$ with a peak distribution in the q12.2-q13 region (an example is shown in Fig. 6, top). Allelic loss of this region has been demonstrated for several tumor types, including breast, prostate, and hepatocellular carcinomas (discussed below).

\section{Discussion}

The transforming proteins of DNA tumor viruses are thought to function by interacting with cellular regulatory proteins. Two cellular proteins that interact with viral transforming proteins are known to function as tumor suppressor proteins. $\mathrm{pRb}$ interacts with adenovirus $\mathrm{E} 1 \mathrm{~A}$, the polyoma virus family large $\mathrm{T}$ antigens, and human papillomavirus (HPV) E7 proteins, and $\mathrm{p} 53$ interacts with SV40 large T, adenovirus E1B, and HPV E6 viral transforming proteins (Lane and Crawford 1979; Linzer and Levine 1979; Sarnow et al. 1982; DeCaprio et al. 

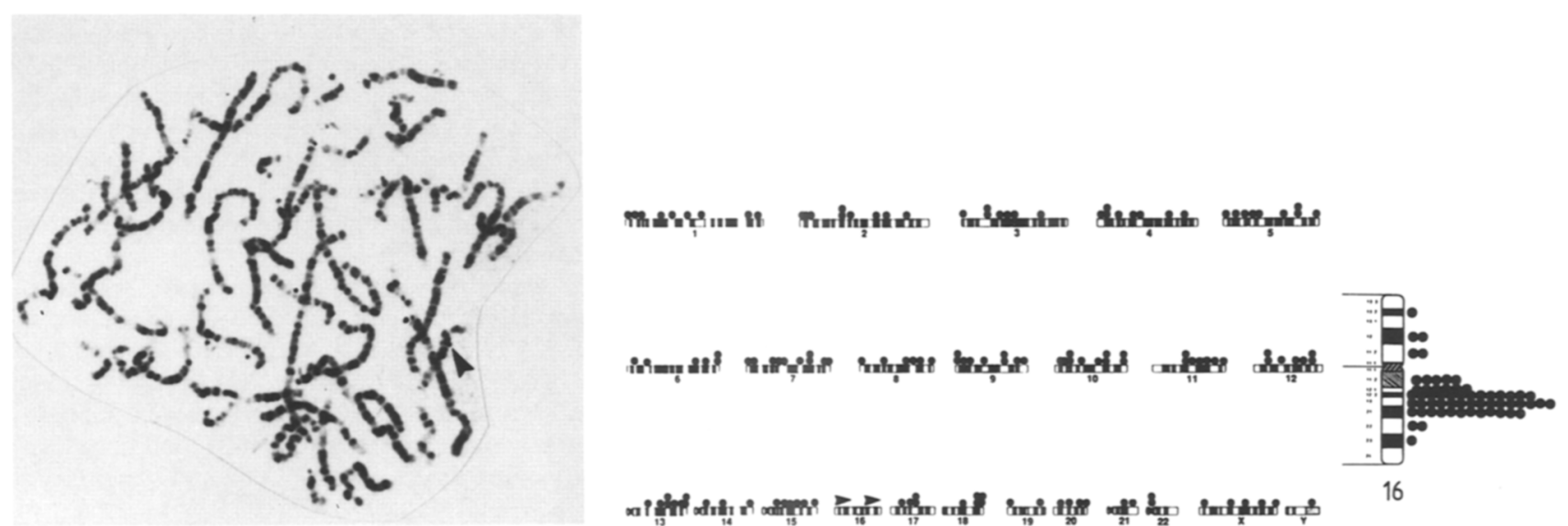

Figure 6. Chromosomal mapping of the pl30 gene. The chromosomal localization of the p130 gene was localized using in situ hybridization of a ${ }^{3} \mathrm{H}$-labeled p130 cDNA probe. (Left) autoradiographic signals observed over 16p12.2 (indicated by arrowhead). (Right) silver grain distribution observed following in situ hybridization of the p130 probe. The positions of 200 silver grains observed over well-banded metaphases were recorded on an ISCN-derived idiogram of the human karyotype.

1988; Whyte et al. 1988; Dyson et al. 1989b; Werness et al. 1990). In each case, it is thought that the interaction with the viral transforming protein antagonizes the normal function of the tumor suppressor protein. p130 represents another cellular target for the adenovirus ElA proteins. Like $\mathrm{pRb}$ and $\mathrm{p} 107, \mathrm{p} 130$ interacts principally with the CR1 and CR2 regions of E1A /Giordano et al. 1991; Dyson et al. 1992). Because these two regions are required for ElA transforming functions, it is likely that cellular proteins interacting with these regions are important regulators of proliferation.

p130 is the third member of the pRb family to be identified. It shares sequence similarity and the ability to bind to E1A with the other known members of this family, pRb and p107 (Harlow et al. 1986; Friend et al. 1987; Ewen et al. 1992; Zhu et al. 1993). Like pRb and p107, p130 can form a complex with E2F transcription factors and is the major E2F partner in $G_{0}$-arrested and early $G_{1}$ fibroblasts (Cobrinik et al., this issue). The immunological cross-reactivity of the $80-$ and $90-\mathrm{kD}$ proteins to p130 and their ability to bind to E1A suggest that the E1A-associated $80-$ and $90-\mathrm{kD}$ proteins may represent additional members of this family. Further study should determine whether these proteins are products of the p130 or p107 genes or whether they are encoded by different genes.

The interaction of p130 with cyclins $\mathrm{A}$ and $\mathrm{E}$ and in vitro phosphorylation of the p130 present in the cyclin complexes is reminiscent of observations of p107/cyclin interactions (Ewen et al. 1992; Faha et al. 1992, 1993). Given the similarity of the spacer regions between $\mathrm{p} 130$ and $\mathrm{p} 107$, and the importance of this region for $\mathrm{p} 107 /$ cyclin A interactions, it is likely that the p130 spacer region is important for the interaction with cyclin $A$. The significance of cyclin $\mathrm{A}$ and cyclin $\mathrm{E}$ interactions with p107 and p130 is currently not known. One possibility is that p130 and p107 are coordinately regulated by phosphorylation through interactions with cyclins A and $\mathrm{E}$.
The apparent interaction of p107, but not p130, with a member of the $\mathrm{D}$ cyclin family is provocative. It has been shown that cyclin Dl/cdk4 complexes can phosphorylate a GST-p107 protein in vitro and cyclins D2 and D3 can interact with a GST-p107 fusion protein in vitro (Matsushime et al. 1992; Ewen et al. 1993). If this interaction facilitates phosphorylation of p107, then D cyclin complexes may differentially regulate p130 and p107. Interestingly, transcriptional induction of $\mathrm{D}$ cyclins has been associated with $G_{0}$ to $G_{1}$ transitions in several cell types (Matsushime et al. 1991; Won et al. 1992). It is during $G_{0}$ and early $G_{1}$ that p130 is the major E2F partner in fibroblasts and p107/E2F complexes are difficult to detect (Cobrinik et al., this issue).

The p130 gene is located on chromosome 16q12.2-13, a region of the genome that undergoes allelic loss or translocation in some human tumors. Loss of the long arm of chromosome 16 has been observed in several types of cancer, including prostate, breast, hepatocellular carcinoma, and others (Carter et al. 1990; Dutrillaux et al. 1990; Tsuda et al. 1990). It is possible that pl30 acts as a tumor suppressor gene in these types of tumors. Further studies on the integrity of the p130 gene in these tumors and in derived cell lines should determine whether or not the pl30 gene is disrupted or mutated.

Using a strategy involving a yeast two-hybrid system to identify cdk2-interacting proteins, another group has isolated a cDNA that has homology to $\mathrm{p} 107$ and $\mathrm{pRb}$ (Hannon et al., this issue). A comparison of their sequence to that of our p130 cDNA revealed that the two are identical.

\section{Materials and methods}

Cell culture

All cells were grown in Dulbecco's modified Eagle media (DMEM) supplemented with $10 \%$ fetal bovine serum except $143 \mathrm{~B}$ cells, which were grown in DMEM supplemented with $10 \%$ bovine calf serum. 


\section{Purification of $p 130$}

The E1A-associated p130 protein was purified from $\sim 5 \times 10^{9}$ 293 cells by coimmunoprecipitation with E1A. Cells were grown to confluency and lysed in E1A buffer (Harlow et al. 1986). E1A and associated proteins were immunoprecipitated using the M73 monoclonal antibody (Harlow et al. 1985) covalently coupled to protein A-Sepharose CL4B (Sigma) using dimethylpimelimidate as described previously (Harlow and Lane 1988). The proteins were eluted by heating the samples to $100^{\circ} \mathrm{C}$ for $3 \mathrm{~min}$ in sample buffer $(312.5 \mathrm{~mm}$ Tris- $\mathrm{HCl}$ at $\mathrm{pH} 6.8,10 \%$ SDS, 500 mM DTT, $0.0025 \%$ bromophenol blue). Sodium iodoacetate was then added to a final concentration of $50 \mathrm{~mm}$ and allowed to react with the proteins for $15 \mathrm{~min}$ at room temperature in the dark. The volume of the sample was reduced by rotary evaporation. Additional DTT was added to $100 \mathrm{~mm}$ and glycerol to $10 \%$, and the sample was heated for $3 \mathrm{~min}$ at $100^{\circ} \mathrm{C}$ before loading onto a $7.5 \%$ SDS-polyacrylamide gel. After electrophoresis, the proteins were electroblotted onto nitrocellulose and visualized by staining with $0.1 \%$ Ponceau $S$ stain in $1 \%$ acetic acid. The band corresponding to the $130-\mathrm{kD}$ E1A-associated protein was cut from the nitrocellulose for further analysis.

\section{HPLC purification and sequencing of p130 tryptic peptides}

In situ typtic digestion of the immobilized p130 was essentially as described previously (Abersold et al. 1987). Tryptic peptides eluted from the nitrocellulose during the enzymatic digestion were separated by narrow-bore reverse-phase HPLC on a HewlettPackard 1090 HPLC equipped with a 1040 diode array detector. Chromatography took place using a Vydac $2.1 \times 150 \mathrm{~mm} \mathrm{C18}$ column and an $\mathrm{H}_{2} \mathrm{O}$ /acetonitrile gradient with trifluoroacetic acid as a counterion. Peptide elution was monitored at 210 and $277 \mathrm{~nm}$, and individual peaks were collected manually and stored at $-20^{\circ} \mathrm{C}$.

Collected peptide samples were applied to polybrene precycled glass fiber filters and placed in the reaction cartridge of an ABI model $477 \mathrm{~A}$ protein sequencer for automated Edman degradation analysis. Chromatographic separation and microsequencing of peptides were essentially as described previously (Ewen et al. 1991).

\section{cDNA cloning}

Based on the amino acid sequences of three of the four sequenced peptides, the following nucleotides were synthesized: $5 '$-GAGTATGTTCTAAGTGTTGGTAAT(T/C)T(A/G)GATGA (1); GAGTATGTTCTATCTGTTGGTAAT(T/C)T/A/G)GATGA (2); and (A/G)TCCAAAATCTGTTCTTCAAT/T/C)TGGTTTAG (3). Oligonucleotides 1 and 2, both derived from peptide 1 , were synthesized separately to reduce degeneracy and were combined in equal proportions for PCR. Total $\lambda$ DNA from a random primed $\lambda \mathrm{gT} 11$ human placental $\mathrm{cDNA}$ library la gift of M. Park, McGill University, Montreal, Canada) was used as a template for PCR reactions. Primers $1 / 2$ and 3 generated a predominant PCR product of $\sim 770$ nucleotides. Sequencing of the PCR product generated using primers $1 / 2$ and 3 revealed an open reading frame with an encoded amino acid sequence homologous to but distinct from p107. Included in the putative sequence was the peptide NILQQHFDK, which had been sequenced in the protein sequence analysis. This $P C R$ product was used as a probe to screen the $\lambda$ gt 11 placental cDNA library. Three positive clones were obtained and found to contain the same cDNA sequence, although the size of the insert varied. The longest positive clone contained a $2.47-\mathrm{kb}$ insert with an open reading frame throughout the entire length of the insert indicating that additional $5^{\prime}$ and $3^{\prime}$ sequences were missing. Using the $3^{\prime} 530$ nucleotides as a probe, an overlapping cDNA of $2.6 \mathrm{~kb}$ was isolated from an oligo(dT)-primed human fetal spleen $\lambda Z A P$ cDNA library (Stratagene). The two cDNAs overlapped by 450 nucleotides of identical sequence. The portion of the cDNA isolated from the fetal spleen library extended the reading frame and included the fourth peptide sequence generated in the protein analysis.

Additional 5' sequences were generated with a 5' RACE (rapid amplification of $\mathrm{cDNA}$ ends) reaction kit (BRL) using the nested primers 5'-GGCACATGCTAACCAATGAAG-3' and 5'-CGGAATTCGATCATTTCCCTCCAGCGTGTAGCTT-3' to amplify poly(A) mRNA from 293 cells. Several cloned copies of the RACE reaction product were sequenced and found to be identical except for varying length at the $5^{\prime}$ end and variability between $\mathrm{T}$ and $\mathrm{C}$ at nucleotide 178 . The longest of these represented an additional 262 nucleotides to the 5 ' end of previously isolated cDNA sequences and probably represents most or all of the $5^{\prime}$ mRNA sequences including the translational initiation site.

Both strands of the cDNA were sequenced using the method of Sanger et al. (1977).

\section{Antibodies}

Monoclonal antibodies to p130 were obtained by immunizing $\mathrm{BALB} / \mathrm{C}$ mice with a GST fusion protein containing p130 amino acid sequences 340-595. Splenocytes from immunized mice were fused to NS-1 murine myeloma cells, and hybridomas were selected in azaserine-hypoxanthine-containing medium (Harlow and Lane 1988). Rabbit anti-peptide antibodies were obtained by immunizing New Zealand white rabbits with bovine serum albumin coupled to specific peptide. To generate anti-peptide sera, the following peptides were used: cyclin D1 KYACTPTDVRDVDI (carboxyl terminus), and p107 KYCKRLQDVVSERANH (carboxyl terminus). Monoclonal antibodies M73 and pAb 419 have been described previously (Harlow et al. 1981,1985 ).

\section{RNA and Northern analysis}

RNA was isolated from cells using a guanidinium- $\mathrm{CsCl}$ method followed by poly(A) selection (Sambrook et al. 1989). The RNA was then separated on a $1 \%$ formaldehyde-agarose gel and transferred to a hybond-N membrane (Amersham). A plasmid containing nucleotides $1078-1866$ of the p130 cDNA was labeled with $\left[{ }^{32} \mathrm{P}\right] \mathrm{dCTP}$ by use of a random priming kit (GIBCO) and used as a probe.

\section{In vitro transcription and translation}

For in vitro transcription, the pl30 cDNA (beginning at nucleotide 286) was cloned into pBS SK (Stratagene). The plasmid was linearized by cutting with $P v u I$, and cRNA was transcribed using T3 RNA polymerase. For in vitro translation, p130 cRNA was translated in rabbit reticulocyte lysate (Amersham) in the presence of $\left[{ }^{35} \mathrm{~S}\right]$ methionine.

\section{Immunoprecipitations and immunoblots}

Immunoprecipitations and immunoblots were performed as described previously (Harlow et al. 1986; Harlow and Lane 1988). Following incubation with the appropriate primary antibody, immunoblots were incubated with an alkaline phosphatase- 
conjugated secondary antibody and proteins were visualized using an Amersham ECL detection system.

\section{Kinase assays}

Immunoprecipitations using the respective antibodies were carried out as described above except that after washing, the protein A-Sepharose pellets were resuspended in $50 \mu \mathrm{l}$ of E1A buffer containing $10 \mathrm{mM} \mathrm{MnCl}$ plus $5 \mu \mathrm{Ci}$ of $\left[\gamma^{32} \mathrm{P}\right] \mathrm{ATP}$ and incubated at $37^{\circ} \mathrm{C}$ for $30 \mathrm{~min}$. The supernatant was then removed and the protein A-Sepharose beads were washed once more with E1A buffer. The samples were then run on a SDSpolyacrylamide gel.

\section{Chromosomal mapping}

The pl30 probe was labeled to a sp. act. of $2 \times 10^{7} \mathrm{cpm} / \mu \mathrm{g}$ DNA with ${ }^{3} \mathrm{H}$-labeled dTTP and ${ }^{3} \mathrm{H}$-labeled dATP (New England Nuclear) using a multiprime DNA labeling system (Amersham). In situ hybridization to BrdU-synchronized peripheral human blood lymphocytes was performed as described previously (Harper and Saunders 1981). Metaphase chromosomes on slides were denatured for $2 \mathrm{~min}$ at $70^{\circ} \mathrm{C}$ in $70 \%$ deionized formamide, $2 \times$ SSC, and then dehydrated with ethanol. The probe mixture consisted of $50 \%$ deionized formamide, $10 \%$ dextran sulfate, $2 \times \operatorname{SSC}(\mathrm{pH} 6.0), 0.2 \mu \mathrm{g} / \mathrm{ml}$ of probe, and $1 \mathrm{mg} / \mathrm{ml}$ of sheared salmon sperm DNA. The probe was denatured in the hybridization solution at $70^{\circ} \mathrm{C}$ for $5 \mathrm{~min}$. Hybridization mixture $(50 \mu \mathrm{l})$ was placed on each slide. Slides were cover-slipped, sealed with rubber cement, and incubated at $37^{\circ} \mathrm{C}$ overnight. Posthybridization washes were $3 \times$ for 3 min each in $50 \%$ deionized formamide, $2 \times$ SSC, and $5 \times$ for 3 min each in $2 \times$ SSC (pH 7.0). The slides were sequentially dehydrated in ethanol and then coated with Kodak NTB $/ 2$ emulsion, exposed for 3 weeks at $4^{\circ} \mathrm{C}$, and developed. Chromosomes were stained with a modified fluorescence, $0.25 \%$ Wright's stain procedure (Lin et al. 1985). The positions of silver grains directly over or touching well-banded metaphase chromosomes were mapped to an ISCN idiogram (Fig. 6).

\section{Acknowledgments}

We gratefully acknowledge the expert technical work of William Lane and colleagues at the Harvard Microchemistry Facility (Harvard University, Cambridge, MA) in performing the in situ tryptic digestion of pl30, and the HPLC separation and microsequencing of p130 tryptic peptides. The excellent technical assistance of Mrs. Linda Anderson in the chromosomal mapping procedures is gratefully acknowledged. We thank D. Cobrinik, A. Scime, and J. Hassell for critical readings of this manuscript. We also thank G. Hannon and D. Beach for openly discussing their results with us before publication. This work was supported with research grants from the Medical Research Council of Canada and the National Cancer Institute of Canada to P.W. and from the Canadian Network of Centres of Excellence to A.M.V.D. P.W. was supported by a career award from the National Cancer Institute of Canada.

The publication costs of this article were defrayed in part by payment of page charges. This article must therefore be hereby marked "advertisement" in accordance with 18 USC section 1734 solely to indicate this fact.

\section{Note added in proof}

Nucleotide sequence data reported in his paper have been submitted to the EMBL, GenBank, and DDBJ data libraries under accession number X76061.

\section{References}

Abersold, R., J. Leavitt, R.A. Saavedra, L.E. Hood, and S.B. Kent. 1987. Internal amino acid sequence analysis of proteins separated by one or two-dimensional gel electrophoresis after in situ protease digestion on nitrocellulose. Proc. Natl. Acad. Sci. 84: 6970-6974.

Bagchi, S., P. Raychaudhuri, and J.R. Nevins. 1990. Adenovirus E1A proteins can dissociate heteromeric complexes involving the E2F transcription factor: A novel mechanism for E1A trans-activation. Cell 62: 659-669.

Bagchi, S., R. Weinmann, and P. Raychaudhuri. 1991. The retinoblastoma protein copurifies with E2F-I, an E1A-regulated inhibitor of transcription factor E2F. Cell 65: 1063-1072.

Bandara, L.R. and N.B. La Thangue. 1991. Adenovirus E1A prevents the retinoblastoma gene product from complexing with a cellular transcription factor. Nature 351: 494-497.

Bellet, A.J., P. Li, E. David, E. Mackey, A. Braithwaite, and J.A. Cutt. 1985. Control function of adenovirus transformation region E1A gene products in rat and human cells. Mol. Cell. Biol. 5: 1933-1939.

Buchkovich, K.J., L.A. Duffy, and E. Harlow. 1989. The retinoblastoma protein is phosphorylated during specific phases of the cell cycle. Cell 58: 1097-1105.

Cao, L., B. Faha, M. Dembski, L.-H. Tsai, E. Harlow, and N. Dyson. 1992. Independent binding of the retinoblastoma protein and p107 to the transcription factor E2F. Nature 355: $176-179$.

Carter, B.S., C.M. Ewing, W.S. Ward, B.F. Treiger, T.W. Aalders, J.A. Schalker, J.I. Epstein, and W.B. Isaacs. 1990. Allelic loss of chromosomes $16 \mathrm{q}$ and $10 \mathrm{q}$ in human prostate cancer. Proc. Natl. Acad. Sci. 87: 8751-8755.

Chellappan, S.P., S. Heibert, M. Mudryi, J.M. Horowitz, and J.R. Nevins. 1991. The E2F transcription factor is a cellular target for the RB protein. Cell 65: 1053-1061.

Chellappan, S., V.B. Kraus, B. Kroger, K. Munger, P.M. Howley, W.C. Phelps, and J.R. Nevins. 1993. Adenovirus ElA, simian virus 40 tumor antigen, and human papillomavirus $\mathrm{E} 7$ protein share the capacity to disrupt the interaction between transcription factor E2F and the retinoblastoma gene product. Proc. Natl. Acad. Sci. 89: 4549-4553.

Chen, P.-L., P. Scully, J.-Y. Shew, J.Y.J. Wang, and W.-H. Lee. 1989. Phosphorylation of the retinoblastoma gene product is modulated during the cell cycle and cellular differentiation. Cell 58: 1193-1198.

Chittenden, T., D.M. Livingston, and W.G. Kaelin Jr. 1991. The T/E1A-binding domain of the retinoblastoma product can interact selectively with a sequence-specific DNA-binding protein. Cell 65: 1073-1082.

DeCaprio, J.A., J.W. Ludlow, J. Figge, J.Y. Shew, C.M. Huang, W.H. Lee, E. Marsilio, E. Paucha, and D.M. Livingston. 1988. SV40 large tumor antigen forms a specific complex with the product of the retinoblastoma susceptibility gene. Cell 54: 275-283.

DeCaprio, J.A., J.W. Ludlow, D. Lynch, Y. Furukawa, J. Griffin, W.H. Piwinica, C.M. Huang, and D.M. Livingston. 1989. The product of the retinoblastoma susceptibility gene has properties of a cell cycle regulatory element. Cell 58: 10851095.

Devoto, S.H., M. Mudryj, J. Pines, T. Hunter, and J.R. Nevins. 1992. A cyclin A-protein kinase complex possesses sequence-specific DNA binding activity: p33cdk2 is a component of the E2F cyclin A complex. Cell 68: 167-176.

Dutrillaux, B., M. Gerbault-Seureau, and B. Zafrani. 1990. Characterization of chromosomal anomalies in human breast cancer. Cancer Genet. Cytogenet. 49: 203-217. 
Dyson, N., K. Buchkovich, P. Whyte, and E. Harlow. 1989a. The cellular $107 \mathrm{~K}$ protein that binds to adenovirus E1A also associates with the large T antigens of SV40 and JC virus. Cell 58: 249-255.

Dyson, N., P.M. Howley, K. Munger, and E. Harlow. 1989b. The human papilloma virus $16 \mathrm{E} 7$ oncoprotein is able to bind the retinoblastoma gene product. Science 243: 934-937.

Dyson, N., R. Bernards, S.H. Friend, L.R. Gooding, J.A. Hassell, E.O. Major, J.M. Pipas, T. Van Dyke, and E. Harlow. 1990. Large $\mathrm{T}$ antigens of many polyomaviruses are able to form complexes with the retinoblastoma protein. J. Virol. 64: 1353-1356.

Dyson, N., P. Guida, K. Munger, and E. Harlow. 1992. Homologous sequences in adenovirus ElA and human papillomavirus E7 proteins mediate interaction with the same set of cellular proteins. I. Virol. 66: 6893-6902.

Egan, C., T.N. Jelsma, J.A. Howe, S.T. Bayley, B. Ferguson, and P.E. Branton. 1988. Mapping of cellular protein-binding sites on the products of early-region $1 \mathrm{~A}$ of human adenovirus type 5. Mol. Cell. Biol. 8: 3955-3959.

Ewen, M.E., J.W. Ludlow, E. Marsilio, J.A. DeCaprio, R.C. Millikan, S.H. Cheng, E. Paucha, and D.M. Livingston. 1989. An $\mathrm{N}$-terminal transforming-governing sequence of SV40 large $\mathrm{T}$ antigen contributes to the binding of both $\mathrm{pl} 10^{\mathrm{Rb}}$ and $\mathrm{a}$ second cellular protein, pl20. Cell 58: 257-267.

Ewen, M.E., Y. Xing, J.B. Lawrence, and D.M. Livingston. 1991. Molecular cloning, chromosomal mapping, and expression of the cDNA for p107, a retinoblastoma gene product-related protein. Cell 66: 1155-1164.

Ewen, M.E., B. Faha, E. Harlow, and D. Livingston. 1992. Interaction of p107 with cyclin A independent of a complex formation with viral oncoproteins. Science 255: 85-87.

Ewen, M.E., H.K. Sluss, C.J. Sherr, H. Matsushime, J. Kato, and D.M. Livingston. 1993. Functional interactions of the retinoblastoma protein with mammalian D-type cyclins. Cell 73: 487-497.

Faha, B., M. Ewen, E. Harlow, and D. Livingston. 1992. Interaction between cyclin $\mathrm{A}$ and adenovirus E1A-associated p107 protein. Science 255: 87-90.

Faha, B., E. Harlow, and E. Lees. 1993. The adenovirus E1Aassociated kinase consists of Cyclin E-p33 cdk2 and cyclin A-p33 cdk2. J. Virol. 67: 2456-2465.

Friend, S.H., J.M. Horowitz, M.R. Gerber, X.-F. Wang, E. Bogenmann, F.P. Li, and R.A. Weinberg. 1987. Deletions of a DNA sequence in retinoblastomas and mesenchymal tumors: Organization of the sequence and its encoded protein. Proc. Natl. Acad. Sci. 84: 9059-9063.

Giordano, A., P. Whyte, E. Harlow, B.R. Franza, D. Beach, and G. Draetta. 1989. A 60 kd cdc2 associated polypeptide complexes with the ElA proteins in adenovirus-infected cells. Cell 58: 981-990.

Giordano, A., C. McCall, P. Whyte, and B.R. Franza. 1991. Human cyclin $A$ and the retinoblastoma protein interact with similar but distinguishable sequences in the adenovirus ElA gene product. Oncogene 6: 481-486.

Hamel, P.A., R.M. Gill, R.A. Phillips, and B.L. Gallie. 1992. Transcription Repression of the E2-containing promoters EI$\mathrm{IaE}$, c-myc, and RB1 by the product of the RBI gene. Mol. Cell. Biol. 12: 3431-3438.

Harlow, E. and D. Lane. 1988. Antibodies: A laboratory manual. Cold Spring Harbor Laboratory. Cold Spring Harbor, New York.

Harlow, E., L.V. Crawford, D.C. Pim, and N.M. Williamson. 1981. Monoclonal antibodies specific for simian virus 40 tumor antigens. J. Virol. 39: 861-869.

Harlow, E., B.R. Franza, and C. Schley. 1985. Monoclonal anti- bodies specific for adenovirus early region 1A proteins: extensive heterogeneity in early region 1 A products. $\%$. Virol. 55: 533-546.

Harlow, E., P. Whyte, B.R. Franza, and C. Schley. 1986. Association of adenovirus early-region 1A proteins with cellular polypeptides. Mol. Cell. Biol. 6: 1579-1589.

Harper, M.E. and G.F. Sauders. 1981. Localization of single copy DNA sequences on G-banded human chromosomes by in situ hybridization. Chromosoma 83: 431-439.

Heibert, S.W., S.P. Chellappan, J.M. Horowitz, and J.R. Nevins. 1992. The interaction of RB with E2F coincides with an inhibition of the transcriptional activity of E2F. Genes \& Dev. 6: $177-185$.

Helin, K., J.A. Lees, M. Vidal, N. Dyson, E. Harlow, and A. Fattaey. 1992. A cDNA encoding a pRb-binding protein with properties of the transcription factor E2F. Cell 70: 337-350.

Houweling, A., P. van den Elsen, and A.J. van der Eb. 1980. Partial transformation of primary rat cells by the leftmost $4.5 \%$ fragment of adenovirus 5 DNA. Virology 105: 537550.

Howe, J.A. and S.T. Bayley. 1992. Effects of Ad5 E1A mutant viruses on the cell cycle in relation to the binding of cellular proteins including the retinoblastoma protein and cyclin A. Virology 186: 15-24.

Hu Q., N. Dyson, and E. Harlow. 1990. The regions of the retinoblastoma protein needed for binding to the adenovirus E1A or SV40 large T antigen are common sites for mutation. EMBO J. 9: 1147-1155.

Huang, S., N.-P. Wang, B.Y. Tseng, W.-H. Lee, and E.H-H.P. Lee. 1990. Two distinct and frequently mutated regions of retinoblastoma protein are required for binding to SV40 T antigen. EMBO J. 9: 1815-1822.

Kaczmarek, L., B. Ferguson, M. Rosenberg, and R. Baserga. 1986. Induction of cellular DNA synthesis by purified adenovirus ElA protein. Virology 152: 1-10.

Kaelin, W.G., M.E. Ewen, and D.M. Livingston. 1990. Definition of the minimal simian virus 40 large $T$ antigen- and adenovirus E1A-Binding Domain in the retinoblastoma gene product. Mol. Cell. Biol. 10: 3761-3769.

Kaelin, W.G., W. Krek, W.R. Sellers, J.A. DeCaprio, F. Ajchenbaum, C.S. Fuchs, T. Chittenden, Y. Li, P.J. Farnham, M.A. Blanar, D.M. Livingston, and E.K. Flemington. 1992. Expression cloning of a cDNA encoding a retinoblastoma-binding protein with E2F-like properties. Cell 70: 351-364.

Kimelman, D., J.S. Miller, D. Porter, and B.E. Roberts. 1985. ElA regions of the human adenoviruses and the highly oncogenic simian adenovirus 7 are closely related. I. Virol. 53: 399-409.

Lane, D.P. and L.V. Crawford. 1979. T antigen is bound to a host protein in SV40-transformed cells. Nature 278: 261-263.

Lees, E., B. Faha, V. Dulic, S.I. Reed, and E. Harlow. 1992. Cyclin $\mathrm{E} / \mathrm{cdk} 2$ and cyclin A/cdk2 kinases associate with p107 and E2F in a temporally distinct manner. Genes \& Dev. 6: 18741885.

Lees, J.A., K.J. Buchkovich, D.R. Marshak, C.W. Anderson, and E. Harlow. 1991. The retinoblastoma protein is phosphorylated on multiple sites by human cdc2. EMBO $I$. 10: 42794290.

Lin, B.T., S. Gruenwald, A.O. Morla, W.H. Lee, and J.Y. Wang. 1991. Retinoblastoma cancer suppressor gene product is a substrate of the cell cycle regulator cdc2 kinase. EMBO $J$. 10: $857-864$.

Lin, C.C., P.N. Draper, and M. Braekeleer. 1985. High resolution chromosomal localization of the B gene of the B globin gene complex by in situ hybridization. Cytogenet. Cell. Genet. 39: $269-274$. 
Linzer, D.I.H. and A.J. Levine. 1979. Characterization of a 54K dalton cellular SV40 tumor antigen present in SV40-transformed cells and uninfected embryonal carcinoma cells. Cell 17: 43-52.

Ludlow, J.W., J.A. DeCAprio, C.-M. Huang, W.-H. Lee, E. Paucha, and D.L. Livingston. 1989. SV40 large T antigen binds preferentially to an underphosphorylated member of the retinoblastoma susceptibility gene product family. Cell 56: $57-65$.

Maruyama, K., S.C. Schiavi, W. Huse, G.L. Johnson, and H.E. Ruley. 1987. Myc and E1A oncogenes alter the responses of PC12 cells to nerve growth factor and block differentiation. Oncogene 1: 361-367.

Matsushime, H., M.F. Roussel, R.A. Ashmun, and C.J. Sherr. 1991. Colony-stimulating factor 1 regulates novel cyclins during the G1 phase of the cell cycle. Cell 65: 701-713.

Matsushime, H., M.E. Ewen, D.K. Strom, J.-Y. Kato, S.K. Hanks, M.F. Roussel, and C.J. Sherr. 1992. Identification and properties of an atypical catalytic subunit $\left(\mathrm{p} 34^{\mathrm{psk}-\mathrm{i} 3} / \mathrm{cdk} 4\right)$ for mammalian D type G1 cyclins. Cell 71: 323-334.

Mihara, K., X.R. Cao, A. Yen, S. Chandler, B. Driscoll, A.L. Murphree, A. T'Ang, and Y.K. Fung. 1989. Cell cycle-dependent regulation of phosphorylation of the human retinoblastoma gene product. Science 246: 1300-1303.

Mudryj, M., S.H. Devoto, S.W. Hiebert, T. Hunter, J. Pines, and J.R. Nevins. 1991. Cell cycle regulation of the E2F transcription factor involves an interaction with cyclin A. Cell 65: 1243-1253.

Nevins, J.R. 1992. E2F: a link between the Rb tumor suppressor protein and viral oncoproteins. Science 258: 424-429.

Pagano, M., G. Draetta, and P. Jansen-Durr. 1992. Association of cdk2 kinase with the transcription factor E2F during S phase. Science 255: 1144-1147.

Peeper, D.S., L.L. Parker, M.E. Ewen, M. Toebes, F.L. Hall, M. $\mathrm{Xu}, \mathrm{A}$. Zantema, A.J. van der Eb, and H. Piwinica-Worms. 1993. A and B type cyclins differentially modulate substrate specificity of cyclin-cdk complexes. EMBO J. 12: 1947-1954.

Phelps, W.C., C.L. Yee, K. Munger, and P.M. Howley. 1988. The human papillomavirus type 16 E7 gene encodes transactivation and transformation functions similar to those of adenovirus E1A. Cell 53: 539-547.

Pines, J. and T. Hunter. 1990. Human cyclin A is adenovirus E1A-associated protein p60 and behaves differently from cyclin B. Nature 346: 760-763.

Ruley, H.E. 1983. Adenovirus early region $1 \mathrm{~A}$ enables viral and cellular transforming genes to transform primary cells in culture. Nature 304: 602-606.

Sambrook, J., E.F. Fritsch, and T. Maniatis. 1989. Molecular cloning: A laboratory manual, 2nd ed. Cold Spring Harbor Laboratory Press, Cold Spring Harbor, New York.

Sanger, F., S. Nicklen, and A.R. Coulsen. 1977. DNA sequencing with chain-terminating inhibitors. Proc. Natl. Acad. Sci. 74: 5463-5467.

Sarnow, P., Y.S. Ho, J. Williams, and A.J. Levine. 1982. Adenovirus E1b-58kd tumor antigen and SV40 large tumor antigen are physically associated with the same $54 \mathrm{kd}$ cellular protein in transformed cells. Cell 28: 387-394.

Schwarz, J.K., S.H. Devoto, E.J. Smith, S.P. Chellappan, L. Jakoi, and J.R. Nevins. 1993. Interactions of the p107 and Rb proteins with E2F during the cell proliferation response. EMBO J. 12: 1013-1020. Shirodkar, S., M. Ewen, J.A. DeCaprio, J. Morgan, D.M. Livingston, and T. Chittenden. 1992. The transcription factor E2F interacts with the retinoblastoma product and a p107-cyclin A complex in a cell cycle-regulated manner. Cell 68: 157-166.

Stabel, S., P. Argos, and L. Philipson. 1985. The release of growth arrest by microinjection of adenovirus E1A DNA. $E M B O$ J. 4: 2329-2336.

Tsai, L.-H., E. Harlow, and M. Meyerson. 1991. Isolation of the human cdk2 gene that encodes the cyclin $\mathrm{A}$ and adenovirus E1A associated p33 kinase. Nature 353: 174-177.

Tsuda, H., W. Zhang, Y. Shimosato, J. Yokota, M. Terada, T. Sugimura, T. Miyamura, and S. Hirohashi. 1990. Allele loss on chromosome 16 associated with progression of human hepatocellular carcinoma. Proc. Natl. Acad. Sci. 87: 67916794.

Webster, K.A., G.E.O. Muscat, and L. Kedes. 1988. Adenovirus ElA products suppress myogenic differentiation and inhibit transcription from muscle-specific promoters. Nature 332: 553-557.

Weintraub, S.J., C.A. Prater, and D.C. Dean. 1992. Retinoblastoma protein switches the E2F site from positive to negative element. Nature 358: 259-261.

Werness, B.A., A.J. Levine, and P.M. Howley. 1990. Association of human papillomavirus types 16 and $18 \mathrm{E} 6$ proteins with p53. Science 248: 76-79.

Whyte, P., K.J. Buchkovich, J.M. Horowitz, S.H. Friend, M. Raybuck, R.A. Weinberg, and E. Harlow. 1988. Association between an oncogene and an anti-oncogene: the adenovirus E1A proteins bind to the retinoblastoma gene product. $\mathrm{Na}$ ture 334: 124-129.

Whyte, P., N. Williamson, and E. Harlow. 1989. Cellular targets for transformation by the adenovirus E1A proteins. Cell 56: 67-75.

Won, K.-A., Y. Xiong, D. Beach, and M.Z. Gilman. 1992. Growth-regulated expression of D-type cyclin genes in human diploid fibroblasts. Proc. Natl. Acad. Sci. 89: 99109914.

Xiong, Y., T. Connolly, B. Futcher, and D. Beach. 1991. Human D-type cyclin. Cell 65: 691-699.

Xiong, Y., J. Menninger, D. Beach, and D.C. Ward. 1992. Molecular cloning and chromosome mapping of CCND genes encoding human D-type cyclins. Genomics 13: 575-584.

Yee, S.-P. and P.E. Branton. 1985. Detection of cellular proteins associated with human adenovirus type 5 early region $1 \mathrm{~A}$ polypeptides. Virology 147: 142-153.

Zamanian, M. and N.B. La Thangue. 1992. Adenovirus E1A prevents the retinoblastoma gene product from repressing the activity of a cellular transcription factor. EMBO J. 11: 26032610 .

- 1993. Transcriptional repression by the RB-related protein p107. Mol. Biol. Cell. 4: 389-396.

Zhu, L., S. van den Heuvel, K. Helin, A. Fattaey, M. Ewen, D. Livingston, N. Dyson, and E. Harlow. 1993. Inhibition of cell proliferation by p107, a relative of the retinoblastoma protein. Genes \& Dev. 7: 1111-1125. 


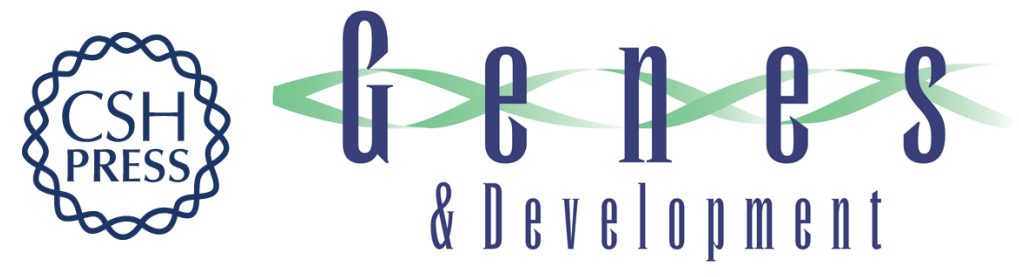

\section{The adenovirus E1A-associated $130-\mathrm{kD}$ protein is encoded by a member of the retinoblastoma gene family and physically interacts with cyclins $A$ and $E$.}

Y Li, C Graham, S Lacy, et al.

Genes Dev. 1993, 7:

Access the most recent version at doi:10.1101/gad.7.12a.2366

References This article cites 82 articles, 28 of which can be accessed free at:

http://genesdev.cshlp.org/content/7/12a/2366.full.html\#ref-list-1

License

Email Alerting Receive free email alerts when new articles cite this article - sign up in the box at the top

Service right corner of the article or click here.

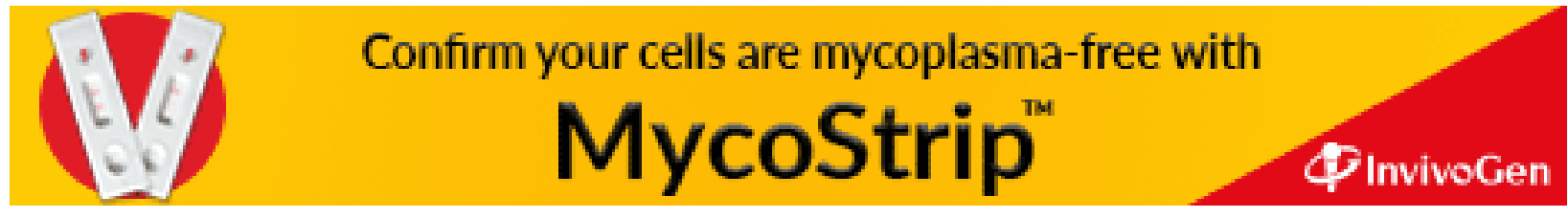

